\title{
Damage Induced Long Noncoding RNA
}

National Cancer Institute

\section{Source}

National Cancer Institute. Damage Induced Long Noncoding RNA. NCI Thesaurus. Code C132163.

Damage induced long noncoding RNA ( 1 kb) is encoded by the human DINOL gene.

This non-coding RNA is involved in p53-dependent gene expression, cell cycle arrest, and apoptosis in response to DNA damage. 